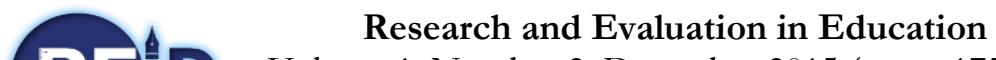

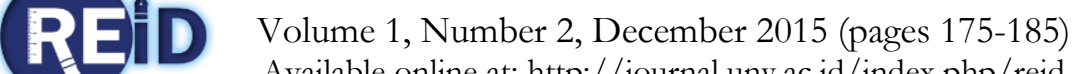 \\ Available online at: http://journal.uny.ac.id/index.php/reid
}

\section{THE EFFECTIVENESS OF WEB-BASED INTERACTIVE BLENDED LEARNING MODEL IN ELECTRICAL ENGINEERING COURSES}

\author{
${ }^{1)}$ Hansi Effendi; ${ }^{2)}$ Soenarto; ${ }^{3}$ Herminarto Sofyan \\ ${ }^{1)}$ Padang State University, Indonesia; ${ }^{23)}$ Yogyakarta State University, Indonesia \\ ${ }^{11}$ hansieffendi@yahoo.com; ${ }^{2}$ narto_elka@yahoo.com; ${ }^{3)}$ hermin@uny.ac.id
}

\begin{abstract}
The study was to test the effectiveness of Web-Based Interactive Blended Learning (WBIBL) model for subjects in the Department of Electrical Engineering, Padang State University. The design employed was a quasi-experimental design with one group pretest-posttest administered to a group of 30 students twice. The effectiveness of WBIBL model was tested by comparing the average pretest scores and the average posttest scores, both in the first trial and the second trial. The average pretest and posttest scores in the first trial were 14.13 and 33.80 subsequently. The increase in the average score was significant at alpha 0.05 . The average pretest and posttest scores in the second trial were 18.67 and 47.03 . The result was also significant at alpha 0.05. The effectiveness of WBIBL model in the second trial was higher than that in the first test. The result was not entirely satisfactory and it might be caused by several weaknesses in both tests, including the limited number of sessions, being only one subject, and the limited number of students as the subjects. However, it could be concluded that the WBIBL model might be implemented as an alternative to the face-to-face instruction.
\end{abstract}

Keywords: instructional model, blended learning, interactive, web-based 


\section{Introduction}

In Law Number 20 Year 2003 regarding the National Education System article 3, it is stated that the function of national education is to develop the national capability and to shape national characteristics as well as national civilization in order to brighten national life. The objective is to develop students' potentials in order to be human beings who have faith and piety toward the Lord the Almighty, to have noble characteristics, to master science, to have capabilities, to be creative and independent, and to become democratic and responsible citizens.

In order to achieve the objective, the government has designed multiple policies and activities that are formulated into fiveyear strategic plannings. One of these plannings is the 2010-2014 Strategic Planning of Indonesian Government with the following missions: (1) to improve the availability of educational service; (2) to expand the accessibility of educational service; (3) to improve the quality and relevance of educational service; (4) to bring into reality the equality in attaining educational service; and (5) to ensure the assurance of attaining educational service.

Although the missions are designed well, in the implementation, there are several constraints found in the reality. The weaknesses are as follows: the educational supporting facilities (in this case the physical facilities) are not sufficient; the number of teaching staff is not sufficient; the students' achievement is still low; the objective of the implemented learning activities is not clear; the curriculum systems are prone to changes; the educational opportunities are not distributed evenly; and the educational costs are relatively expensive (Soekatarwi, 2007, pp.4-19).

In line with the problems explained, with the effective implementation of the Teacher and Lecturer Law regarding the Teacher Sertification, the teachers and lecturers are motivated to continue their study. In Law Number 14 Year 2005, it has been formulated that: 'Teachers should have academic qualifications, competencies, educational certificates, physical and mental health and capability in order to materialize the objectives of national education' (Article 8). The academic qualifications mentioned in Article 8 will be attained by means of higher education in bachelor and diploma programs (Article 9).

On the other hand, the requirements regarding the lecturers are formulated in Law Number 14 Year 2005 Article 45 and the lecturers should have the following minimum requirements: (1) Should be the graduates of masters programs for the diploma or the bachelor degree; and (2) Should be the graduates of doctoral programs for the postgraduate degree (Verse 2). In Article 47 Verse 1 , it is added that the educator certificates for the lecturers as mentioned in Article 45 shall be given after the lecturers meet the following requirements: (1) having been working as educators in higher education for at least two years; (2) having an academic position at least as an expert assistant; (3) having been graduated from the certification conducted by the universities that run the educational staff provision programs and the universities that run the intended program should be appointed by the Government.

Due to those regulations, the teachers assigned in the remote areas are motivated to continue their studies. However, state universities have limited capacities in absorbing these teachers, while there are many private universities but these universities are less qualified in comparison to the state ones. In addition, the tuition fee in private universities is expensive. As a result, these teachers decide to continue their study in state universities. Unfortunately, at the same time, the number of lecturers who teach in state universities is limited because most of these lecturers are also continuing their study, attending multiple training program, and performing tri dharma (teaching, research, and community service) activities in the university level in order to improve their competencies. As a result, the ratio between the students and the lecturers becomes very high. The high ratio has been becoming another problem in the implementation of education. 
One of the ways for overcoming the problem is by utilizing the Information and Communication Technology (ICT) in the teaching-learning process. The researchers expect that by utilizing ICT in teaching, some of the teaching problems such as infrastructure costs, teach-ing staff quantity, educational access, and educational fees might be overcome. In other words, ICT might be utilized to reduce the infrastructure costs, increase the quantity of teaching staffs, expand the educational access, and reduce the educational fees.

The use of Information and Communication Technology in ongoing teaching-learning process is appropriate to be implemented in Indonesia because the program is compatible to the Republic of Indonesia characteristics, namely: (1) the Republic of Indonesia is an archipelagic country that has unequal people distribution; (2) the ICT-based teaching supporting infrastructures are quite sufficient (especially the telephone network); (3) the number of the internet users and stations is quite plenty; (4) Indonesian people are more aware of investment toward the educational domain; and (5) the universities still have low absorbing capacity (Soekartawi, 2007, pp.910). With the existence of ICT-based teaching program, educational programs are expected to expand to the remote areas, and the community members will be motivated to continue their study.

In addition, the implementation of ICTbased teaching is supported by the government. Several legal aspects that support the implementation of ICT-based teaching are as follows: National Education System Act Number 20 Year 2003; Minister of National Education Decree Number 107/U/2001 regarding the Implementation of Distance Learning; Circular of the Directorate General of Higher Education Number 3040/D/ T/2005 regarding the Explanation of Remote Class dated on September $8^{\text {th }}$, 2005; Minister of National Education Explanation dated on September $1^{\text {st }}, 2005$; and governing law regulations and policies. Based on the aforementioned regulations, the government allows universities to implement the infomation and technology-based distance learning because of educational cost effectiveness and efficiency; however, the information and technologybased distance learning should be implemented based on the regulations and procedures that are already formulated.

The use of Information and Communication Technology development in teaching has been brought into reality by employing web-based learning/e-learning implementation. Cheng (2005, p.34) states that there has been a change of paradigm in the learning process, and in the new paradigm, there has been new characteristics, namely: (1) life long learning, (2) multiple sources of learning and teaching, and (3) globally and locally networked learning and teaching. On the other hand, pedagogic environment has been globally connected by some aspects, such as: (1) self-learning program and package; (2) interactive multimedia material; (3) web-based learning; (4) outside expert; and (5) local and global exchange program. Similarly, the information and technology pedagogic environment for the students and the lecturers has been connected by the following aspects: (1) webbased learning; (2) interactive self-learning; (3) multimedia facilities and learning material; (4) interactive self-learning; dan (5) video conferencing.

The comparison of the new learning paradigm and the old learning paradigm is displayed in Table 1. Table 1 shows that the teachers or the lecturers do not become the single source; instead, they become facilitators, motivators, catalysts or mediators for the students. The students are also demanded to be active, independent, full of initiatives and analytical in the learning process. Therefore, the web-based learning that will be developed should be based on the students' demands (student-centered, webbased learning), should be mastered independently (self-learning), should be focused on the learning manners, should have sufficient sources in supporting the learning process (multiple sources), should not be limited to time and space, and should also be interactive. 

Table 1. Changes in the Learning Paradigm

\begin{tabular}{ll}
\hline \multicolumn{1}{c}{ New CMI-Tripilization Paradigm } & \multicolumn{1}{c}{ Traditional Site-Bounded Paradigm } \\
\hline Individualized Learning: & Reproduced Learning: \\
Student is the centre of Education & Student is the Follower of Teacher \\
Individualized Programs & Standard Programs \\
Self-Learning & Absorbing Knowledge \\
Self-Actualizing Process & Receiving Process \\
Focus on How to Learn & Focus on How to Gain \\
Self Rewarding & External Rewarding \\
Localized and Globalized Learning: & Institution-Bounded Learning: \\
Multiple Sources of Learning & Teacher-Based Learning \\
Networked Learning & Separated Learning \\
Lifelong and Everywhere & Fixed Period and Within Institution \\
Unlimited Opportunities & Limited Opportunities \\
World-Class Learning & Site-Bounded Learning \\
Local and International Outlook & Mainly Institution-based Experiences \\
\hline
\end{tabular}

(Source: Cheng, 2005, p.29)

Naidu (2006, pp.4-7) also states that there are several superiorities in developing the web-based learning programs namely: (1) the learning program is very dynamic and might be displayed in multiple interesting, attractive and interactive forms; (2) the learning program might be operated all time so that the students and the lecturers might attain information regarding the necessary learning materials; (3) the learning program might be implemented individually, where each student might select the learning form or the learning model that might be more relevant to his or her background; and (4) the learning program is comprehensive and provides multiple learning forms from multiple sources that enable the students to select the available learning format, learning method, and/or practice.

With all of the available technology, web-based learning provides opportunities for designing the authentic environment such as contextual learning and problem-based learning; as a result, the students will have 'learning by doing' experiences. Even Lehmann and Chamberlin (2009, p.2) believe if the webbased learning is well-managed, it might have better performance than the traditional learning under the following considerations: the students should be active, the learning materials should be up-to-date, there should be an interaction between the students and the learning contents, there should be an interaction between the students and the lecturers, the idea exploration should be deep, and all of the discussions should be recorded. In addition, the use of web-based learning should make the learning more effective due to the learning concept such as repetition in which the students might repeat the learning materials as often as possible. The reason is that the learning materials are available 24 hours a day and seven days a week.

The Faculty of Engineering, Padang State University, is elligible to implement the missions of higher education that have been formulated in the higher-education strategic planning, which includes improving education availability, expanding educational accessibility, improving education quality and relevance, realizing education equality, and ensuring the certainty in attaining higher education service. However, in order to accomplish these missions, there have been limitations in the available resources.

The use of e-learning is viewed as one of the alternatives that might be used to overcome the limitations that exist in the available resources. Naidu (2006, p.2) states that the use of ICT might improve rapidly especially in universities because technology has been considered as a way of improving learning access to the information source as well as a way of decreasing educational cost. However, the use of e-learning in the learning process in universities is not as easy as 
flipping our hands, because e-learning demands multiple prerequisites that might be hard to accomplish.

Since the publication of the regulations, both at the level of Educational Minister and Directorate General of Higher Education, which regulate the implementation of remote learning, the Faculty of Engineering, Padang State University has expanded e-learning. Specifically, it has prepared a sufficient webbased learning system. However, the use of the system has not been optimum.

There are several problems that have been identified regarding the reasons why the already possessed e-learning has not been optimally benefitted. One of the problems is that both the students and lecturers have not been accustomed to attend and implement the e-learning (Effendi, 2005, p.18). Both the students and lecturers might need motivations and good examples in relation to the use of elearning.

Through the assistance of Islamic Development Bank, Padang State University has implemented the training programs for lecturers. The university serves as the designer of the e-learning training program so that the lecturers will have sufficient competencies for benefitting all of the available information and communication technologies as their teaching media. However, in reality both at the Department of Electrical Engineering and at other departments of Padang State University, there has not been much web-based learning developed by the lecturers.

On the other hand, there has been a small group of lecturers who develop and use e-learning. Most of the e-learning forms are turning face-to-face presentation into web presentation in the form of texts and/or documents. Certainly, such a use is not incorrect, but the lecturers might gain more benefits by using all of the strengths possessed by the information and communication technology since the technology is able to integrate multiple systems of symbols into the learning process. In addition, the e-learning developed by the lecturers has not fully implemented the appropriate learning theories and learning methods in order to create effective and interesting learning situations.
The package of e-learning materials that does not garner the benefits ICT definitely becomes less useful for the students with several differences. For example, the different learning styles possessed by the students should also be given attention in developing the learning forms including the e-learning ones.

The students and lecturers, for years, have been accustomed to face-to-face learning model. In this model, the interaction, in terms of students' control toward the learning process, is very limited. Some people argue that the use of ICT for the learning process has caused the occurence of social isolation due to the decrease in the interaction both between the students and the lecturers and among the students themselves in the classroom. In order to overcome the problem, the researchers would like to develop a blended learning one of whose characteristics is being interactive. The blended learning is basically able to overcome the problem of interaction within the learning process. Lawhead and Rosbottom (Anggarwal, 2003, p.399) believe that the combination of two learning methods (in this case, face-to-face and online) will make the learning process more effective.

From the students' point of view, it has been apparent that the students have been accustomed to the student-centered learning. They have not been fully aware that the responsibility of learning process in the new paradigm is on their own hand.

One of the blended learning models that has been developed is Web-Based Interactive Blended Learning Model (WBIBLM). The model refers to the appropriate learning theory and learning method. Then, the term interactive refers to the fact that the learning will focus on the students (student-centered learning) and will be fully controlled by the students (studentcontrolled learning). The model also has complete learning components and considers the students' needs and learning styles (Effendi, 2015, pp.16-17).

The model emphasizes the aspect of interaction between the students and learning materials, between the students and lecturers, and among the students themselves. The 
interaction between the students and learning materials is designed by using the component display theory that is proposed by Merrill. Meanwhile, the interaction between the students and lecturers is designed by using the facility of direct and indirect discussions, which is provided by the moodle-based online learning system. As a result, the blendedlearning model is based on the combination of constructivism paradigm, interactivity principles, and learning styles, which are the aspects given attention in the the Web-Based Interactive Blended Learning Model.

Based on the background of the study, the problem in the study can be formulated as follows: What is the effectiveness of the WebBased Interactive Blended Learning Model (WBIBLM) in improving the like of learning achievement? Therefore, the objective of the study is to test the effectiveness of WBIBLM in improving the learning achievement of the students.

\section{Research Method}

Type

The study was quasi-experimental with one group pre-test and post-test design. The study might be described as follows:

$$
\mathrm{O}_{1} \quad \mathrm{X} \quad \mathrm{O}_{2}
$$

Figure 1. Experimental Design

Note:

$\mathrm{O}_{1}=$ Pre-test

$\mathrm{O}_{2}=$ Post-test

$\mathrm{X}=$ Experiment

\section{Research Setting}

The study was conducted in the even semester (January-June) of 2014 Academic Year and the odd semester (July-December) of 2015 Academic Year. The study was held at the Department of Electrical Engineering, the Faculty of Engineering, Padang State University.

\section{Subjects/Targets}

The subjects in the study were a learning group that consisted of 30 students who took the Electrical Machines subject at the Electrical Engineering Department, the Faculty of Engineering, Padang State University. They were selected randomly by implementing purposive random sampling technique.

\section{Research Procedure}

There were two experiments in the study, namely the first experiment and the second experiment. The first experiment was conducted in eight sessions for the materials of transformator within the learning group. Three out of the eight sessions $(37.50 \%)$, namely sessions one, five, and eight, were conducted by means of face-to-face learning in the classroom, while five out of the eight sessions $(62.50 \%)$ were conducted by using the web-based e-learning.

The initial meeting was used for explaining every single aspect that was related to WBIBLM and for administering the pretest. Session five was used for having a class discussion regarding the materials that the students had not mastered. Session eight was used for administering post-test.

The selection of one group pre-test and post-test design was primarily based on the limited learning group; there was only one learning group that consisted of 30 students. Several weaknesses of the design were as follows: (a) there had not been any guarantee that the model would be the sole factor that cuased the differences between the results of the pre-test and post-test; and (b) the impacts of history, maturation, testing, instrument, regression, selection and mortality might not be avoided (Creswell, 2014, pp.245-246).

However, the selection of the design also had several benefits. The primary benefit was that the pre-test provided an opportunity for the researchers to compare the achievement of the same subjects before and after the administration of the WBIBLM.

\section{Data, Instrument, and Data Gathering Technique}

The data which were gathered in the study were the scores of the pre-test and posttest in the Electrical Machines 1 subject for the topic of transformator. The data were 
gathered by means of a learning achievement test which had been initialized by designing the test guidelines. The test guidelines included five topics, namely: (a) working principles and construction of one-phased transformator; (b) vector diagram and circuit use of one-phased replacement; (c) transformator loading according to the load type and voltage regulation according to the loading type; (d) parralel performance and voltage regulation of the one-phased transformator load; and (e) working principles and construction of three-phased transformator and the connections.

Based on those test guidelines, the learning achievement test items were constructed. In order to guarantee that the test guidelines and test items had a content validity, two lecturers of subject-matter of Electrical Machines 1 and two other lecturers validated the test guidelines and test items. The expert validation was performed from February $8^{\text {th }}$ to February $15^{\text {th }}, 2014$.

In addition, the quality of the learning achievement test was measured by means of a content validity test that was performed in the first and second experiments. The content validity test was performed by employing point-biserial correlation. The test followed the opinion proposed by Mardapi (2004, p.27) who states that if the score is performed under dichotomous manner ( 1 for each correct answer and 0 for each incorrect answer), then the implemented correlation technique is point-biserial.

The results of the first field experiment showed that 25 out of 54 test items were totally valid. In addition, five test items (test item number 4, 9, 11, 20 and 30) could not answered and four test items (test item number 5, 6, 8 and 24) could be completed correctly. The invalid test items, including the easiest ones and hardest ones, were revised for the second field experiment. In addition, based on the expert judgement, the number of the test items should be expanded to 60 items. In the second field experiment, the overall 60 test items were valid.

The reliability estimation of the learning achievement test was conducted in two ways. First, the researchers measured the experts consistency or the experts agreement regarding learning achievement test. The aspects of the learning achievement test that the researchers asked for the expert judgment were the test substance, form and language. The experts agreement was measured by means of inter-rate reliability (Mardapi, 2012, p.86). After the inter-rater consistency had been calculated, the researchers found that the inter-rater coefficient was 0.73. The coefficient showed that $73.00 \%$ of the raters agreed with the judged aspects of learning achievement test. Theoretically, the correlation coefficient above 0.70 is very good (Streiner \& Norman, 2000; Polgar \& Thomas, 2000). Second, the researchers administered an internal reliability test in order to ensure that all of the items provided similar results. The result of the internal reliability test for the first field experiment was 0.744 (KR-20), while the result of the internal reliability test for the second field experiment was 0.954 (KR-20).

As to the data gathering technique, the researchers employed learning achievement test results in the form of pre-test and posttest. The pre-test and post-test were administered before and after the administration of the Web-Based Interactive Blended Learning Model in order to measure the learning effectiveness by using the developed model.

\section{Data Analysis Technique}

In data analysis technique, the following techniques were employed: (1) internal consistency analysis of reliability by means of KR-20 for the instrument of learning achievement test items whose item scores were dichotomous ( 1 or 0 ); and (2) t-test for testing the effective-ness of the Web-Based Interactive Blended Learning Model by comparing the results of the pre-test and post-test.

\section{Findings and Discussions}

The first field experiment was conducted to a learning group that consisted of 48 students. After the second week, five students withdrew from the learning group. There 
were 30 students who fully participated in the classroom activity. The learning materials of transformator that became the example of development consisted of eight sessions: three sessions $(37.50 \%)$, namely sessions one, five, and eight, were conducted in the face-to-face learning manner, while the remaining five sessions $(62.50 \%)$ were conducted through elearning activities.

The initial meeting was used for explaining every single aspect that was related to the e-learning and for administering the pre-test. In addition, the researchers also motivated the students to implement the Web-Based Interactive Blended Learning Model (WBIBLM). Session five was used for having a class discussion regarding the learning materials that the students had not mastered and it served as a formative action.
The effectiveness test for the WebBased Interactive Blended Learning Model was implemented by comparing the scores of the pre-test and the post-test. The scores of learning achievement in the first field experiment are shown in Table 2. In the first field experiment, the researchers found that the learning by means of the Web-Based Interactive Blended Learning Model could attain only $62.59 \%$ of the learning achievements. In general, the increase from the pretest results to the post-test results was $36.42 \%$. However, based on the findings the differences between the pre-test scores and the post-test scores are not very high but the scores from both tests are significantly different.

Table 2. The Effectiveness of the WBIBLM in the First Experiment

\begin{tabular}{lrrrrr}
\hline \multirow{2}{*}{ Test Period } & \multicolumn{3}{c}{ Score } & Deviation \\
\cline { 2 - 5 } & Maximum (\%) & Minimum (\%) & Mean (\%) & Standard & Note \\
\hline Pre-test & $5(9.26)$ & $20(37.00)$ & $14.13(26.17)$ & 3.52 & $\mathrm{P}<0.05$ \\
Post-test & $19(35.19)$ & $38(70.37)$ & $33.80(62.59)$ & 4.49 & \\
Increase & $17(25.93)$ & $18(33.37)$ & $19.67(36.42)$ & - & \\
\hline
\end{tabular}

The second field testing also served as the main field testing. The objective of the second field testing was to test and to see how far the expectations of the model use had been met. The design of the second field testing was similar to that of the first field testing, namely the one-group pre-test and post-test. The results of the second field testing are displayed in Table 3.
Based on the results in Table 3, the effectiveness of the Web-Based Interactive Blended Learning Model is achieved around $78.00 \%$ of the learning objectives. If the pretest results are compared to the post-test results, in general, the increase is $47.28 \%$. Although the increase is not high, it is significant.

Table 3. The Effectiveness of the WBIBLM in the Second Experiment

\begin{tabular}{lrrrrr}
\hline \multirow{2}{*}{ Test Period } & \multicolumn{3}{c}{ Score } & Deviation & Note \\
\cline { 2 - 4 } & Minimum (\%) & Maximum (\%) & Mean (\%) & Standard & (\%) \\
\hline Pre-test & $10(16.67)$ & $25(42.67)$ & $18.67(31.11)$ & 3.87 & \\
Post-test & $17(28.33)$ & $59(98.33)$ & $47.03(78.39)$ & 12.87 & $\mathrm{P}<0.05$ \\
Increase & $14(23.33)$ & $35(58.00)$ & $28.37(47.28)$ & - & \\
\hline
\end{tabular}

Table 3 shows that $60 \%$ of the participants were able to achieve more than $78 \%$ of the learning objectives. The position of each participant might be viewed from the pre-test and post-test results that are displayed in Figure 2, which show that the participants who earned higher scores in the pre-test tended to earn higher scores in the post-test. After these results were analyzed further, it is found that the correlation between the pretest scores and the post-test scores is 0.86 , which is significant. 


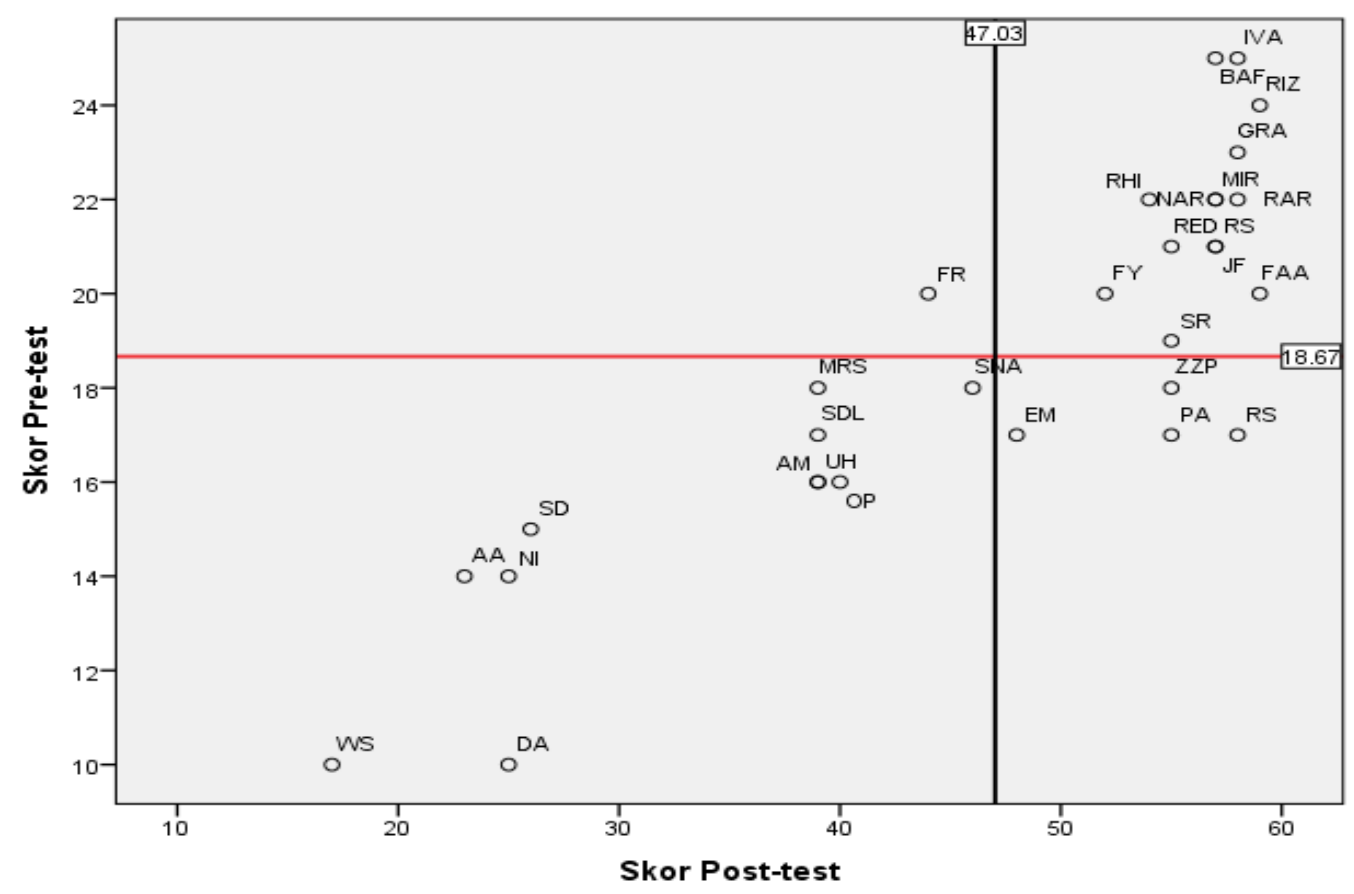

Figure 2. The Position of Each Participant based on the Pre-Test and Post-Test Results

The comparison on the effectiveness of the Web-Based Interactive Blended Learning Model that had been measured by comparing the general percentage of learning achievements between the first and second field experiments is displayed in Figure 3. The increase of learning achievement achievement from the first field experiment to the second field experiment is $15 \%$ and even more.

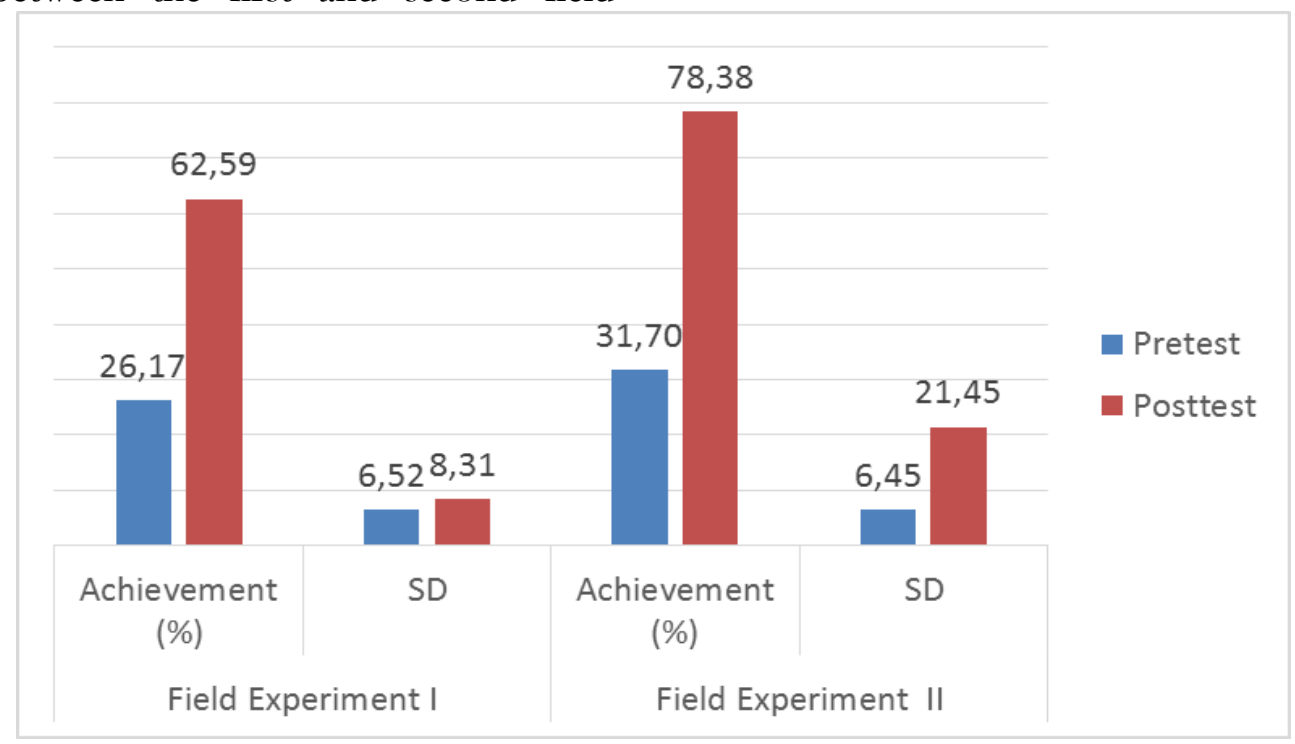

Figure 3. The Comparison on the Effectiveness of the WBIBLM between the First and Second Field Experiments

The effectiveness of the WBIBLM was $78.39 \%$. The model was not significantly effective but the study on the model had informed that the WBIBLM might be used as an alternative for the face-to-face lectures. Within the study, WBIBLM was implemented in the following composition: $37.50 \%$ face-toface learning and $62.50 \%$ online learning. The composition showed that the subject might save $62.50 \%$ of the educational resources such as classrooms, lecturers, and subject assisting tools. 
Despite the effectiveness, other limitations of the study on the model might not also be avoided. The limitations on the research and development toward WBIBLM are as follows. First, the researchers lost five respondents from the study and the lost is one of the consequences in implementing a research and development study within a certain period of time. The study was conducted for eight weeks and, as a result, the researchers were not able to avoid the situations in which the students withdrew themselves as the research subject or they did not play their role as the subject completely. The withdrawal might be caused by one of the regulations which state that in the second week, the students might change their study activities. In addition, for certain reasons, there were some students who did not completely attend the research activity. For example, the initial number of students in the Electrical Machines 1 in the second field testing was 43 people. After the second week, the number decreased to 35 people. However, there were 30 students who completely attended the activity. Second, there was not any control group and this situation had been the consequence of implementing the onegroup pre-test and post-test design. The researchers did not have any other choice because there was only one learning group in the Electrical Machines 1 subject.

\section{Conclusions and Suggestions}

Conclusions

The effectiveness of the Web-Based Interactive Blended Learning Model (WBIBLM) was tested by comparing the pretest and post-test scores both in the first and second field experiments. From the first field experiment, the average pre-test score was 14.13 and the average post-test score was 33.80. The increase in the average score was significant at alpha 0.05 . In the second field experiment, the average pre-test score was 18.67 and the average post-test score was 47.03. The increase on the average score was significant as well at alpha 0.05 . However, the effectiveness result in the second field testing was higher than that of in the first field testing.

The effectiveness of implementing the WBIBLM achieved only $78.39 \%$. Such result is not significant; however, the study on the model at least has concluded that WBIBLM might be used as an alternative for some of the face-to-face lectures.

\section{Suggestions}

The development of WBIBLM might be continued by creating a stronger design. Probably, future researchers might use control groups, more subjects, longer period and more comparisons between face-to-face learning and e-learning to produce a more effective and reliable WBIBLM.

\section{References}

Cheng, Y.C. (2005). New paradigm for reengineering education: Globalization, localization, and individualization. Dordrecht, Netherland: Springer.

Creswell, J.W. (2014). Research design: Pendekatan kualitatif, kuantitatif, dan mixed Research design: Qualitative, quntitative, and mixed approach]. (A. Fawaid, Trans.). Yogyakarta: Pustaka Pelajar.

Directorate General of Higher Education. (2005). Surat edaran Dirjen Dikti Nomor 3040/D/T2005 tentang penye-lenggaraan kelas jarak jauh [Circular of the Directorate General of Higher Education Number 3040/D/T.2005, about the implementation of distance learning]. Jakarta.

Directorate General of Higher Education. (2005). Surat edaran Direktur Jenderal Pendidikan Tinggi Nomor 3040/D/ T2005, 8 September 2005, penjelasan tentang penyelenggaraan kelas jarak jauh [Circular of the Director General of Higher Education Number 3040/D/ T.2005, 8 September 2005, explanation on the implementation of distance learning]. Jakarta.

Effendi, H. (2015). Model blended learning interaktif berbasis web mata kuliah mesin-

The effectiveness of web-based interactive blended learning model... - 184 Hansi Effendi, Soenarto, \& Herminarto Sofyan 
mesin listrik di Fakultas Teknik Universitas Negeri Padang [Web-based interactive blended learning model in the subjects of electricity machines in the Faculty of Engineering of Padang State University] (Unpublished doctoral dissertation). Universitas Negeri Yogyakarta, Indonesia.

Lehmann, K., \& Chamberlin, L. (2009). Making the move to e-learning: Putting your course online. New York, NY: Rowman and Littlefield Education.

Mardapi, D. (2004). Penyusunan tes hasil belajar [Learning outcomes test arrangement]. Yogyakarta: Pascasarjana UNY.

Mardapi, D. (2012). Pengukuran, penilaian, dan evaluasi pendidikan [Educational measurement, assessment, and evaluation]. Yogyakarta: Nuha Medika.

Merrill, M.D. (1981). Component display theory. New Jersey: Educational Technology Publication Englewood Cliffs.

Merrill, M.D., \& Twitchell, D.G. (1994). Instructional display theory. New Jersey: Educational Technology Publication Englewood Cliffs.

Minister of National Education. (2001). Keputusan Mendiknas No. 107/4/2001 tentang penyelenggaraan program pendidikan tinggi jarak jaub [The judgment of the Minister of national education number $107 / 4 / 2001$ about the implementation of distance higher education program]. Jakarta.

Minister of National Education. (2005). Penjelasan Mendiknas 1 September 2005 tentang penyelenggaraan kelas jarak jauh [Explanation of the Minister of national education 1 September 2005 about the implementation of distance course]. Jakarta.
Ministry of Education and Culture. (2013). Rencana strategis kementerian pendidikan dan kebudayaan 2010-2014 [Strategic plan of the ministry of education and culture, 2010-2014]. Jakarta.

Ministry of National Education. (2001). Keputusan Menteri Pendidikan Nasional Republik Indonesia Nomor 107/U/2001 tentang penyelenggaraan program pendidikan jarak jaub [The judgment of the Minister of national education of Indonesian Republic Number 107/ U/2001 about the implementation of distance learning]. Jakarta.

Naidu, S. (2006). E-learning: A guide book of principles, procedures, and practice. New Delhi: Creative Workshop.

Polgar, S., \& Thomas, S.A. (2000). Introduction to research in the health sciences. London: Churchill Livingstone/ Harcourt.

Republic of Indonesia. (2003). Undang-Undang R.I. Nomor 20 Tabun 2003 \& Peraturan Pemerintah R.I. Tabun 2010. Sisdiknas dan penyelenggaraan pendidikan dan wajib belajar [Act no 20 Year 2003 \& Government Regulation Year 2010. National education system and the implementation of education and compulsory learning].

Republic of Indonesia. (2005). Undang-Undang Republik Indonesia No. 14 Tabun 2005 tentang Guru dan Dosen [Act No. 14 Year 2005 about Teachers and Lecturers].

Soekartawi. (2007). Merancang dan menyelenggarakan e-learning [Designing and implementing e-learning]. Yogyakarta: Ardana Media dan Rumah Produksi Informatika.

Streiner, D.L., \& Norman, G.R. (2000). Health measurement scales: A practical guide to their development and use. Oxford: Oxford University Press. 